\title{
Evaluating Changes to Prevented Planting Provision on Moral Hazard
}

\author{
Christopher N. Boyer* (D) and S. Aaron Smith \\ Department of Agricultural and Resource Economics, University of Tennessee, Knoxville, Tennessee, USA \\ *Corresponding author. Email: cboyer3@utk.edu
}

\begin{abstract}
Prevented planting provision in crop insurance protects producers from failure to plant attributable to natural causes. We determined the impact of this provision at various crop insurance coverage levels on prevented planting claims and ex post moral hazard. The moral hazard incentive in the prevented planting provision is stronger for corn than soybeans. Reducing the prevented planting coverage factor for corn could likely reduce moral hazard, but the degree of the reduction will likely depend on the revenue protection coverage level. Conversely, we found moral hazard is unlikely to occur for soybean production regardless of the revenue protection coverage level.
\end{abstract}

Keywords: Crop insurance; moral hazard; prevented planting; yield response function

JEL Classifications: Q12; Q18

\section{Introduction}

Increases in prevented planting indemnity payments over the last two decades have triggered investigations into prevented planting claims (Rejesus, Escalante, and Lovell, 2005; Rejesus et al., 2003; U.S. Department of Agriculture, Office of Inspector General [USDA-OIG], 2013). Rejesus et al. (2003) and Rejesus, Escalante, and Lovell (2005) concluded the prevented planting provision was more vulnerable to fraudulent claims than other crop insurance provisions and plans. The higher potential for fraud is linked to the current prevented planting provision allowing for the indemnity payment to exceed the costs to date invested in the crop, encouraging producers to accept the prevented planting payment instead of producing a harvested crop (Rejesus, Escalante, and Lovell, 2005; Rejesus et al., 2003). An audit by the USDA-OIG (2013) confirmed these concerns, reporting that prevented planting indemnities paid to producers exceeded their estimated losses from 2008 to 2011 by more than $\$ 480$ million.

Prevented planting coverage has existed since the early 1970s but became a basic component of crop insurance by the Federal Crop Insurance Reform and Department of Agriculture Reorganization Act of 1994 (U.S. Congress, 1994) with the purpose of decreasing the need for ad hoc disaster assistance for producers. Under the current prevented planting provision, Revenue Protection (RP), Revenue Protection with the Harvest Price Exclusion, Yield Protection, and Area Risk Protection Insurance crop insurance policies provide producers with an indemnity payment if they are impeded from planting an insured crop by a designated final planting date or within any applicable late planting period because of natural causes (U.S. Department of Agriculture, Federal Crop Insurance Corporation, 2015). The final planting date is the last day producers could plant the insured crop and still be eligible for the full coverage of 
their insurance policy. The late planting period begins the day after the final planting date for the insured crop and ends 20-25 days after the final planting date. ${ }^{1}$

If the insured crop qualifies for a prevented planting indemnity, the producer has three basic options. The producer could plant the originally insured crop during the late planting period, but the producer's coverage (revenue or yield guarantee) would reduce $1 \%$ for each day, after the final planting date, that the insured crop is planted. Another option would be to plant a second crop after the late planting period and receive a prevented planting payment equal to $35 \%$ of the full prevented planting payment guarantee. The producer could plant an uninsured short season crop such as an annual grass for haying and/or grazing. Finally, the producer could leave the acreage unplanted and receive the full prevented planting indemnity payment. Prior to 2017, the full prevented planting payment was typically $60 \%$ of the original guarantee for the crop insurance policy (i.e., prevented planting coverage factor). The full prevented planting payment requires the producer to leave the land fallow or plant a summer cover crop after the late planting period. However, the producer cannot harvest the cover crop before November 1. Additionally, this option does not affect the producer's actual production history (APH), a 4- to 10-year trendadjusted average yield used for future crop insurance purchases.

No publicly available data exist on what happens to prevented planting indemnified acres; however, the report by USDA-OIG (2013) mentioned that only $0.1 \%$ of producers receiving a prevented planting payment were planting a second crop or planting during the late planting period. Thus, the vast majority of producers were leaving land fallow during the growing season. They concluded that the current policy was encouraging inefficient land use as well as potentially increasing soil erosion and enhancing weed seed banks on fallowed acres. This has raised concerns about moral hazard in prevented planting, but little research exists on the moral hazard in prevented planting (Kim and Kim, 2018; further discussion is provided in Section 2).

In response to these concerns, the U.S. Department of Agriculture, Risk Management Agency (USDA-RMA) made slight modifications to the prevented planting payment structure in 2017 by decreasing the prevented planting coverage factor for corn from $60 \%$ to $55 \%$ of the insured coverage guarantee under their crop insurance policy (USDA-RMA, 2016). ${ }^{2}$ This change was made to more accurately align prevented planting indemnities with the estimated preplanting costs for corn (USDA-RMA, 2016). The prevented planting coverage factor was not adjusted for other commodities, but USDA-RMA indicated that coverage factors for other crops will likely be adjusted in the future (USDA-RMA, 2016).

The objective of this research is to explore the implications of changing the prevented planting coverage factor on producers' production decisions and moral hazard. We determine how changes to the prevented planting coverage factor affect corn and soybean producers' decision to plant their insured crop during the late planting period or abandon production by accepting the prevented planting indemnity payment. We also assess possible policy changes to the prevented planting provision that could be considered by the USDA-RMA when making future adjustments to the full prevented planting payment coverage factor.

\section{Moral hazard in prevented planting}

Moral hazard in crop insurance occurs when the insured producer becomes less inclined to protect against indemnified outcomes because of the protection provided by the insurance. Literature on moral hazard in crop insurance typically focuses on moral hazard before the loss has occurred (i.e., ex ante moral hazard) (Babcock and Hennessy, 1996; Coble et al., 1997; Horowitz and Lichtenberg, 1993; Miranda and Glauber, 1997; Roberts, Key, and O’Donoghue, 2006; Sherriff,

\footnotetext{
${ }^{1}$ Final planting date and late planting periods vary by crop and region.

${ }^{2}$ Prevented planting coverage can be increased to $60 \%$ or $65 \%$ for corn and $65 \%$ or $70 \%$ for soybeans. Additional premiums would be incurred by the producer for the added coverage.
} 
2005; Smith and Goodwin, 1996). For example, several studies have estimated how input decisions (i.e., fertilizer and chemicals), during production, change when the crop is insured before the crop is indemnified. Overall, these studies have reported mixed evidence of ex ante moral hazard in crop insurance (Roberts, Key, and O'Donoghue, 2006). Moral hazard in prevented planting differs from these studies because a producer's decision to continue with planting during the late planting period or not produce a crop and accept the prevented planting payment occurs after the loss (i.e., ex post moral hazard) (Kim and Kim, 2018). This type of moral hazard would exist if an insured producer chose to not produce a crop and take the indemnity payment despite planting during the late planting period being a profitable option.

Rejesus et al. (2003) and Rejesus, Escalante, and Lovell (2005) showed the prevented planting provision would likely cause a producer to accept the full indemnity payment despite being able to plant during the late planting period. This would result in insured producers prematurely abandoning production for an indemnity payment, which is what the USDA-OIG (2013) observed in their audit of prevented planting claims. Kim and Kim (2018) investigated how crop insurance buy-up coverage level affects moral hazard in prevented planting for Iowa corn production. They used a simulation model to show that producers with higher buy-up coverage levels of crop insurance were less likely to plant during the late planting period than taking the prevented planting payment. These studies suggest the prevented planting provision may promote moral hazard among insured producers by changing their action from planting to not producing a crop and taking the indemnity payment.

Kim and Kim (2018) assumed a corn yield distribution that was constant over the late planting period and did not consider yields declining as planting date was delayed. This is a weak assumption given that the agronomic literature shows yields decline as planting date is extended (Boyer et al., 2015; Darby and Lauer, 2002; Epplin, Hossain, and Krenzer, 2000; Hossain, Epplin, and Krenzer, 2003; Lauer et al., 1999). Agronomic data showing that yield declines as planting is prolonged suggest the producer's decision to plant during the late planting period or take the prevented planting payment depends on the planting date during this period. Using agronomic data to evaluate moral hazard in prevented planting would build on Kim and Kim's (2018) work as well as provide a base for exploring potential policy changes to the prevented planting provision that would minimize moral hazard.

Furthermore, the current prevented planting provision does not require producers to plant a cover crop on indemnified acres (U.S. Department of Agriculture, Federal Crop Insurance Corporation, 2015). However, the U.S. Department of Agriculture, National Resource Conservation Service (USDA-NRCS, 2013) encourages producers to plant a summer cover crop on indemnified acres because research shows planting cover crops can improve soil health, decrease nutrient leaching, improve water quality, and reduce soil erosion. Considering the current provision could be causing land to be prematurely removed from production, the provision could also be increasing the likelihood of soil erosion and resistant weed seed banks on the indemnified acres (USDA-NRCS, 2013). Requiring producers to plant a cover crop on indemnified acres would decrease producer returns from abandoning the crop and accepting the prevented planting payment. Amending this provision could partially mitigate moral hazard by encouraging more producers to plant a cover crop and reduce adverse environmental effects on indemnified acres.

\section{Economic framework}

We are interested in evaluating producers' decision to plant their insured crop during the late planting period or take the prevented planting payment, leaving the land fallow. A producer can also plant a second crop; however, this option is not considered in this analysis. Most producers select a crop for the upcoming year over the winter and prepurchase inputs for the crop. The cost of transitioning, which might include management time, machinery, and inputs, and 
other environmental factors would likely keep producers from planting an alternative crop (insured or not insured). This is why we did not consider planting a second crop in the analysis, but including this option in the economic model would be a logical extension of this work.

We assume the producer's decision to plant during the late planting period or take the prevented planting payment is based on the objective of maximizing profit. If the producer purchases revenue protection crop insurance, which includes the prevented planting provision (55\% for corn and $60 \%$ for soybean), and is prevented from planting the crop, the crop insurance policy guarantees the producer will receive an indemnity payment based on the revenue guarantee. The revenue guarantee is determined by APH yield $\left(y^{A P H}\right)$; the guaranteed price $\left(p^{G}\right)$ set by the USDA-RMA, which is the highest of the project price and the harvest price; and a buy-up coverage level $(\theta \in[50 \%, 85 \%])$. The premium, $I C(\theta)$, increases as the coverage buy-up level increases. Additionally, the decision to take the prevented planting payment will depend on the projected spot price received by the producer at harvest $\left(p^{m}\right)$, the projected cost of production both prior to planting $(P P C)$ (i.e., chemical, land rent, and machinery) and after planting $(P C)$, and projected harvested yield $(y)$. Assuming the producer has passed the final planting date for his or her insured crop, we can mathematically express the producer's profit function as

$$
\pi=\max \left\{\max \left[p^{m} y(\text { day }), p^{G} y^{A P H} \psi(\text { day })\right]-P P C-P C-I C(\theta), p^{G} y^{A P H} \theta \delta-P P C-I C(\theta)\right\},
$$

where $\pi$ is profit; $y($ day $)$ is the projected harvested yield and is a function of the planting date day ( day $=1$ on January 1 of each year); $\delta$ is the percentage of the guaranteed coverage the producer receives if he or she was unable to plant and land remains fallow (i.e., prevented planting payment coverage factor); and $\psi$ is the crop insurance buy-up coverage level on the day the crop was planted. Coverage level on the day the crop was planted will be different from the coverage level when the policy was purchased $(\theta)$ when planting occurs after the final planting date $(F D)$ designated in the crop insurance policy. The producer's coverage decreases $1 \%$ per day after the final planting date, $\psi=\theta-0.01 \times($ day $-F D)$.

Equation (1) can be reduced for the various scenarios. If the producer makes no insurance claim, the producer's net returns from planting $\left(\pi_{p}\right)$, equation $(1)$ is reduced to

$$
\pi_{p}=p^{m} y(\text { day })-P P C-P C-I C(\theta) .
$$

If the revenue at harvest is less than the guaranteed revenue, the producer's net returns from the guaranteed revenue protection $\left(\pi_{R P}\right)$ is expressed as

$$
\pi_{R P}=p^{m} y(\text { day })+\left[p^{G} y^{A P H} \psi(\text { day })-p^{m} y(\text { day })\right]-P P C-P C-I C(\theta) .
$$

The producer's indemnity payment $\left[p^{G} y^{A P H} \psi(\right.$ day $)-p^{m} y($ day $\left.)\right]$ is paid if guaranteed revenue is greater than the revenue received at harvest. Finally, if the producer makes a prevented planting claim, the producer's net returns from accepting the prevented planting payment $\left(\pi_{p p}\right)$ are shown as

$$
\pi_{p p}=p^{G} y^{A P H} \theta \delta-P P C-I C(\theta) .
$$

Figure 1 displays an example of how profits might change over the planting window. The decision to plant late or accept the full prevented planting payment occurs after the final planting date $(F D)$. At this point, producers are certain about their profit from accepting the prevented planting payment $\left(\pi_{p p}\right)$ because the preplanting production costs and insurance premium have occurred and the producers know their guaranteed revenue. The profit from the guaranteed revenue protection $\left(\pi_{R P}\right)$ is also constant until the designated final planting date. After this date, coverage levels decrease $1 \%$ per day during the late planting period. However, the producer profits from planting $\left(\pi_{p}\right)$ are decreasing over the planting window. Market price can be set with forward contracts and/or hedging strategies, and production costs can be estimated during the production 


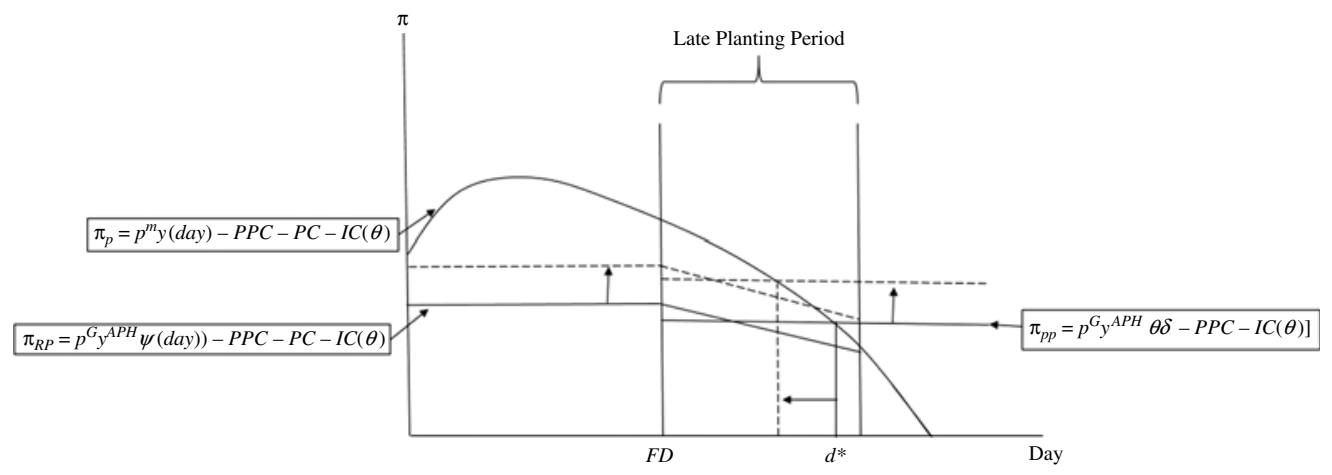

Figure 1. Example of how an insured producer's profits might change over the late planting period

period. The decline in profits from planting is linked to yield decreasing as the planting date prolongs. In Figure 1, a profit-maximizing producer would plant the crop until $d^{\star}$, at which point the producer would take the prevented planting payment.

Figure 1 also demonstrates how a higher purchased buy-up level (shown in the dashed line in Figure 1) increases the profit from the revenue protection payment and profit from the prevented planting payment. Higher buy-up coverage shifts $d^{*}$ to an early date in the late planting period. The producer has fewer days to plant before the prevented planting payment is more profitable than planting. Thus, a higher coverage level would likely result in producers choosing to take the prevented planting payment over planting late, which is what Kim and Kim (2018) observed.

Solving equation (1) for $d^{*}$ cannot be found analytically because of the spine in the decisionmaking problem. However, we can determine $d^{*}$ when a producer would increase profits from accepting the prevented planting payment over planting late. We can estimate yield response to planting date to determine the profit from planting over the planting window. We can explore how crop insurance coverage level and recent changes to the prevented planted payment coverage factor affect the decision to take the prevented planting payment over planting late as well as moral hazard.

\section{Estimation and policy analysis}

A quadratic response function is a common functional form used for estimating yield response to planting date (Julian day-starting at 1 January of each year) (Boyer et al., 2015; Darby and Lauer, 2002; Epplin, Hossain, and Krenzer, 2000; Hossain, Epplin, and Krenzer, 2003; Lauer et al., 1999). We estimate yield response to Julian day following this specification, which is expressed as

$$
y_{t i}=\beta_{0}+\beta_{1} D_{t i}+\beta_{2} D_{t i}^{2}+v_{t}+\varepsilon_{t i},
$$

where $y_{t i}$ is yield in year $t$ for crop $i ; D_{t i}$ is Julian day when the crop was planted; $\beta_{0}, \beta_{1}$, and $\beta_{2}$ are coefficients; $v_{t} \sim N\left(0, \sigma_{v}^{2}\right)$ is the year random effect; and $\varepsilon_{t i} \sim N\left(0, \sigma_{\varepsilon}^{2}\right)$ is the random error term. The two error terms were assumed to be independent. Equation (5) is estimated with maximum likelihood using the MIXED procedure of SAS 9.4 (SAS Institute Inc., 2013). We tested the yields for heteroskedasticity with respect to time using the likelihood ratio test. If heteroskedasticity was present, we report the results for the model that adjusts for the unequal variances by year. We can find the yield maximizing planting date by solving the first-order condition of equation (5) with respect to planting day. Finding the yield maximizing planting date will validate that these data are representative of the data used by the USDA-RMA to determine the boundaries of planting window designed in the crop insurance. 
Figure 2. Corn yields (bu./acre) across Julian planting date from 2010 to 2014 at Milan, Tennessee

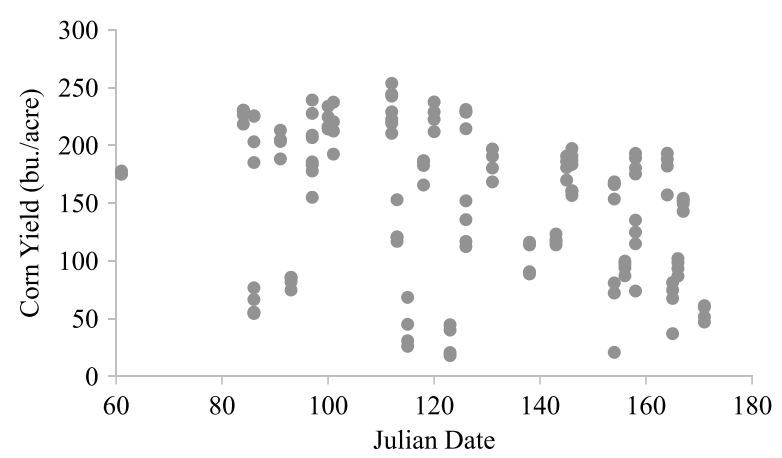

Figure 3. Soybean yields (bu./acre) across Julian planting date from 2008 to 2010 at Milan, Tennessee

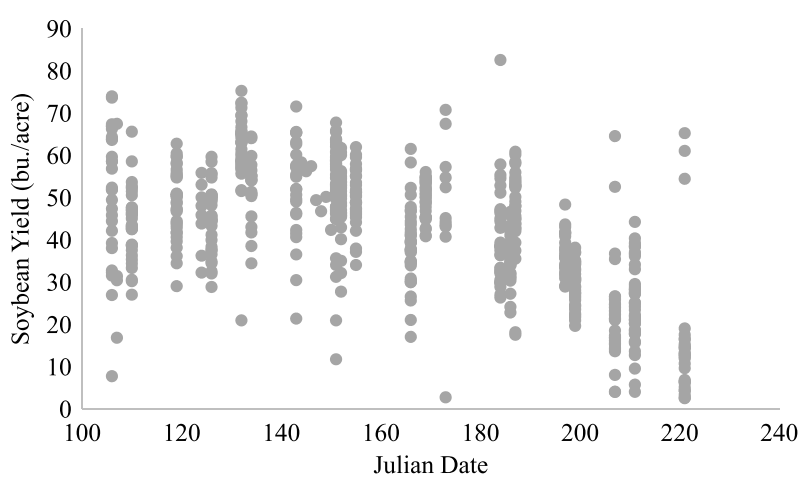

Equation (5) is substituted into equation (1), and profits from planting are estimated. This indicates the date at which the producer would be better off taking the prevented planting payment instead of planting during the late planting period. For both corn and soybeans, these analyses are performed when the purchased coverage levels are $\theta=60 \%, 70 \%$, and $80 \%$. For each of these coverage levels, we assume the prevented planting payment coverage factors to be $\delta=50 \%$, $55 \%$, and $60 \%$. For each of the prevented planting payment coverage factors, we also estimate how a hypothetical provision requiring cover crops to be planted on indemnified prevented planted acres affects a producer's decision. This hypothetical provision would result in producers accepting the prevented planting claim to plant a cover crop, increasing their costs.

\section{Data}

Agronomic data were used from two field experiments conducted in Tennessee. The corn yield data came from a nonirrigated planting date experiment conducted at the University of Tennessee Research and Education Center, Milan, Tennessee, from 2010 to 2014. The experiment was a randomized complete block design with four replications. The main plots in the experiment were six planting windows starting in late March and ending in late June. The final planting date for Tennessee corn is May 20, and the late planting period is 25 days (June 14). Data from this experiment fall within the planting window of interest in this study. Figure 2 shows a plot of corn yields across planting dates.

Soybean yield data come from a nonirrigated planting date experiment conducted at the University of Tennessee Research and Education Center, Milan, Tennessee, from 2008 to 2010. The experiment included soybeans of maturity groups (MGs) II, III, IV, and V. The main plot treatments were four MGs (II, III, IV, and V), the subplots were two seeding rates, and sub-subplots were seven planting dates. There were no differences in yield across MGs; thus, we estimated soybean 
Table 1. Summary of data used to calculate profits and crop insurance payments

\begin{tabular}{|c|c|c|c|}
\hline Data & Symbol & Corn & Soybean \\
\hline Market price $(\$ / \mathrm{bu})$. & $p^{m}$ & $\$ 5.15$ & $\$ 11.87$ \\
\hline Guaranteed price with revenue protection ( $\$ / \mathrm{bu}$.) & $p^{G}$ & $\$ 5.35$ & $\$ 12.09$ \\
\hline APH yield (bu./acre) & $y^{A P H}$ & 152 & 43 \\
\hline Preplanting production cost (\$/acre) & $P P C$ & $\$ 148$ & $\$ 152$ \\
\hline Postplanting production cost (\$/acre) & $P C$ & $\$ 399$ & $\$ 256$ \\
\hline Cover crop cost (\$/acre) & CC & $\$ 51.20$ & $\$ 51.20$ \\
\hline Revenue protection $60 \%$ coverage premium ( $\$$ /acre) & $I C(\theta)$ & $\$ 9$ & $\$ 17$ \\
\hline Revenue protection $70 \%$ coverage premium (\$/acre) & $I C(\theta)$ & $\$ 15$ & $\$ 25$ \\
\hline Revenue protection $80 \%$ coverage premium ( $\$ /$ acre) & $I C(\theta)$ & $\$ 42$ & $\$ 62$ \\
\hline
\end{tabular}

Note: Basic unit structure was used to find crop insurance premiums.

yield response to planting date combining the MGs. In each year, soybeans were planted form late April to late July. The final planting date for soybeans in Tennessee is June 15, and the late planting period is 20 days (July 5). Data from this experiment fall within the planting window of interest in this study. Figure 3 shows a plot of soybean yields across planting dates.

Table 1 lists parameters used in the simulations. Data were averages for Tennessee from 2011 to 2016. We used this time frame because the corn and soybean price guaranteed with revenue protection in Tennessee was only available from 2011 to 2016 (USDA-RMA, $2017 \mathrm{~b}$ ). The market prices were the average corn and soybean prices in Tennessee from 2011 to 2016 (U.S. Department of Agriculture, National Agricultural Statistical Service [USDA-NASS], 2018). APH yields were assumed to be the average corn and soybean yields from the experiments. Crop insurance premiums for producers were found using the online USDA-RMA (2017a) cost estimator. We used the average producer premium paid for revenue protection with 60\%, 70\%, and 80\% coverage in Gibson County from 2011 to 2016, with basic unit structure.

Average production costs from 2011 to 2016 were estimated using the University of Tennessee Crop Budgets for nonirrigated, no-till soybean and corn production (University of Tennessee, Department of Agricultural and Resource Economics, 2017). Preplanting costs included land rent, chemical costs for burndown and preemergent, and machinery. We assumed producers could return their other inputs, such as seed and fertilizer, if they were unable to plant; thus, these costs were not included as a preplanting cost. The preplanting costs were subtracted from the total production costs to determine the postplanting production costs.

The cost of the summer cover crop was developed following the USDA-NRCS (2013) recommendations. Producers have several options when selecting a cover crop for indemnified prevented planting acres, but USDA-NRCS (2013) recommends selecting a high biomass, warm-season annual grass to protect against soil erosion and increase organic biomass. We assumed the producer would plant sorghum-sudangrass grass at $30 \mathrm{lb}$./acre, which follows University of Tennessee Extension (2018) seeding recommendations. The total cost of the cover crop was estimated to be $\$ 51.20 /$ acre, with seed costing $\$ 30 /$ acre and a machinery cost of $\$ 21.20$ /acre.

\section{Results and discussion}

\subsection{Yield response}

Table 2 shows the results of the yield response function (equation 2) to planting date for corn and soybeans. The intercept, linear, and quadratic parameter estimates were significant at the 0.05 
Table 2. Parameter estimates for the corn and soybean yield response function to planting date

\begin{tabular}{|c|c|c|}
\hline Parameter & Corn & Soybean \\
\hline Intercept $\left(\beta_{0}\right)$ & $108.66^{\star \star}$ & $-59.38^{\star \star}$ \\
\hline Slope $\left(\beta_{1}\right)$ & $2.6099^{\star \star \star}$ & $1.5828^{\star \star \star}$ \\
\hline Quadratic $\left(\beta_{2}\right)$ & $-0.0159^{\star \star \star}$ & $-0.0056^{\star \star \star}$ \\
\hline-2 Log likelihood & $1,310.7$ & $4,904.2$ \\
\hline Akaike information criterion & $1,320.7$ & $4,918.2$ \\
\hline Bayesian information criterion & $1,318.7$ & $4,911.9$ \\
\hline Number of observations & 140 & 660 \\
\hline
\end{tabular}

Notes: Single, double, and triple asterisks $\left({ }^{*},{ }^{\star \star},{ }^{\star \star \star}\right)$ represent significance at the $10 \%, 5 \%$, and $1 \%$ level. Units are reported in bu./acre.

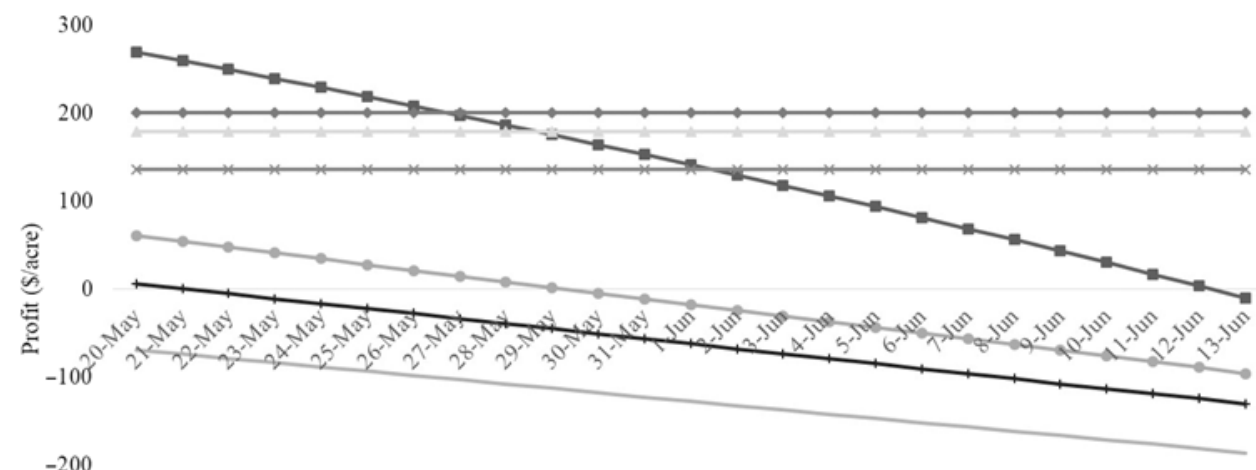

$-200$

$-300$

Planting Day

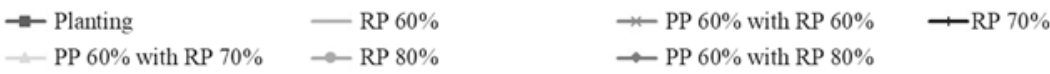

Figure 4. Estimated profits from planting, revenue protection (RP) with $60 \%, 70 \%$, and $80 \%$ coverage, and prevented planting indemnity payment (PP) with a prevented planting coverage factor of $60 \%$ for corn over the late planting period

level for corn and soybeans. Heteroskedasticity was detected and corrected for both corn and soybeans; thus, we report the results that adjust for the unequal variances. The positive value for the linear parameter estimate and the negative sign for the quadratic parameter estimates indicate that yields were increasing at a decreasing rate as planting date was lengthened. The yield maximizing planting date was March 23 for corn and May 19 for soybeans. These optimal planting dates fall within the planting window for the revenue protection policy and align with University of Tennessee recommendations.

\subsection{Policy analysis}

Figure 4 shows profits over the late planting period from planting; revenue protection (RP) with $60 \%, 70 \%$, and $80 \%$ coverage; and prevented planting indemnity payment (PP) for each of the coverage levels with the 2016 prevented planting coverage factor for corn $(\delta=60 \%)$. The figure demonstrates how yield decline over the late planting period affects the profitability of planting in this time frame. Profit-maximizing producers would choose to plant corn until June 2, May 29, and May 27 for revenue protection coverage levels of $60 \%, 70 \%$, and $80 \%$, respectively. After these 
dates, producers would abandon production and select the prevented planting indemnity payment. Corn producers in the late planting period (i.e., after the loss has occurred) would have only a few days when planting would be more profitable than taking the indemnity payment and abandoning production. This might explain why the vast majority of producers do not plant during the late planting period (USDA-OIG, 2013).

We find that corn production would remain profitable until around June 12; however, these profits would be lower than the profits from the prevented planting indemnity payment. For example, if corn was planted on June 4 , producers would make about $\$ 100 /$ acre, but this return would be $\$ 30 /$ acre, $\$ 70 /$ acre, and $\$ 95 /$ acre less than receiving the indemnity payment for prevented planted insurance buy-up levels of $60 \%, 70 \%$, and $80 \%$, respectively. Thus, producers would be abandoning profitable corn production for prevented planting payments from revenue protection crop insurance. The finding suggests moral hazard exists in the prevented planting provision because producers would be better off abandoning profitable corn production and taking their indemnity for the majority of the days in the late planting period. Furthermore, as coverage level increases from $60 \%$ to $80 \%$, the number of planting days in the late planting period when planting would be optimal decreases. Thus, higher coverage levels provide producers with a greater incentive to abandon profitable corn production and accept the prevented planting payment, which is what Kim and Kim (2018) observed, further displaying a moral hazard problem with the prevented planting provision.

In addition, the provision is likely increasing federal crop insurance expenditures by paying producers to abandon profitable production and overcompensating producers for their losses. We present results for two potential policy recommendations that could be implemented to mitigate moral hazard and reduce federal crop insurance expenditures. Table 3 shows the planting date in the late planting period when a profit-maximizing corn producer would select the indemnity payment over planting when the prevented planting payment coverage factor is reduced and when producers are required to plant a cover crop.

Reducing the prevented planting coverage factor for corn to $55 \%$, which has been implemented for 2017 by the USDA-RMA, does extend the number of planting days in the late planting period before the prevented planting payment would become more profitable (Table 3). Profitmaximizing producers would choose to plant corn until June 6 , June 3 , and June 2 for revenue protection coverage levels of $60 \%, 70 \%$, and $80 \%$, respectively (Table 3 ). This suggests the recent revision to the prevented planting coverage factor for corn made by the USDA-RMA in 2017 would likely reduce moral hazard in prevented planting, but the degree of the reduction will likely depend on the revenue protection coverage level.

We also impose another hypothetical reduction to prevented planting coverage factor for corn to $50 \%$. At this coverage factor, producers would have to wait until the last 6-10 days of the 25-day late planting period before they abandon planting corn for the indemnity payment. This change might increase producers' commitment to planting during the late planting period.

Finally, we present results if there was an enforced requirement to plant a summer cover crop on indemnified acres. This requirement decreases the profitability of abandoning the crop, and accepting the prevented planting payment would decrease, which extends the number of planting days in the late planting period before the prevented planting payment would become more profitable (Table 3). Also, indemnified acres would be covered over the summer months, reducing potential for soil erosion and weed seedbeds to be generated. This hypothetical provision change appears to also reduce moral hazard in prevented planting for corn.

The results for soybean production are reported in Figure 5 and Table 4. Moral hazard does not appear to be a concern for soybean production. At the current prevented planting coverage factor of $60 \%$, profit-maximizing producers would choose to plant in the late planting period over abandoning production and taking the indemnity payment (Figure 5). This result holds true regardless of the revenue protection coverage level (Table 4). Thus, reducing the prevented planting coverage 
Table 3. Planting day in the late planting period when the profit from prevented planting payment becomes greater than profits from planting corn

\begin{tabular}{|c|c|c|c|}
\hline Policy Scenario & $\begin{array}{l}\text { Revenue Protection with } \\
60 \% \text { Coverage Level }(\theta)\end{array}$ & $\begin{array}{l}\text { Revenue Protection with } \\
70 \% \text { Coverage Level }(\theta)\end{array}$ & $\begin{array}{l}\text { Revenue Protection with } \\
80 \% \text { Coverage Level }(\theta)\end{array}$ \\
\hline \multicolumn{4}{|c|}{ Prevented planting payment coverage factor $(\delta)$ of $60 \%$} \\
\hline $\begin{array}{l}\text { Without cover crop } \\
\text { restriction }\end{array}$ & June 2 & May 30 & May 27 \\
\hline $\begin{array}{l}\text { With cover crop } \\
\text { restriction }\end{array}$ & June 6 & June 3 & June 1 \\
\hline \multicolumn{4}{|c|}{ Prevented planting payment coverage factor $(\delta)$ of $55 \%$} \\
\hline $\begin{array}{l}\text { Without cover crop } \\
\text { restriction }\end{array}$ & June 6 & June 3 & June 2 \\
\hline $\begin{array}{l}\text { With cover crop } \\
\text { restriction }\end{array}$ & June 10 & June 7 & June 6 \\
\hline \multicolumn{4}{|c|}{ Prevented planting payment coverage factor $(\delta)$ of $50 \%$} \\
\hline $\begin{array}{l}\text { Without cover crop } \\
\text { restriction }\end{array}$ & June 8 & June 5 & June 4 \\
\hline $\begin{array}{l}\text { With cover crop } \\
\text { restriction }\end{array}$ & June 12 & June 9 & June 8 \\
\hline
\end{tabular}

Note: The late planting date for Tennessee corn is May 20 through June 14.

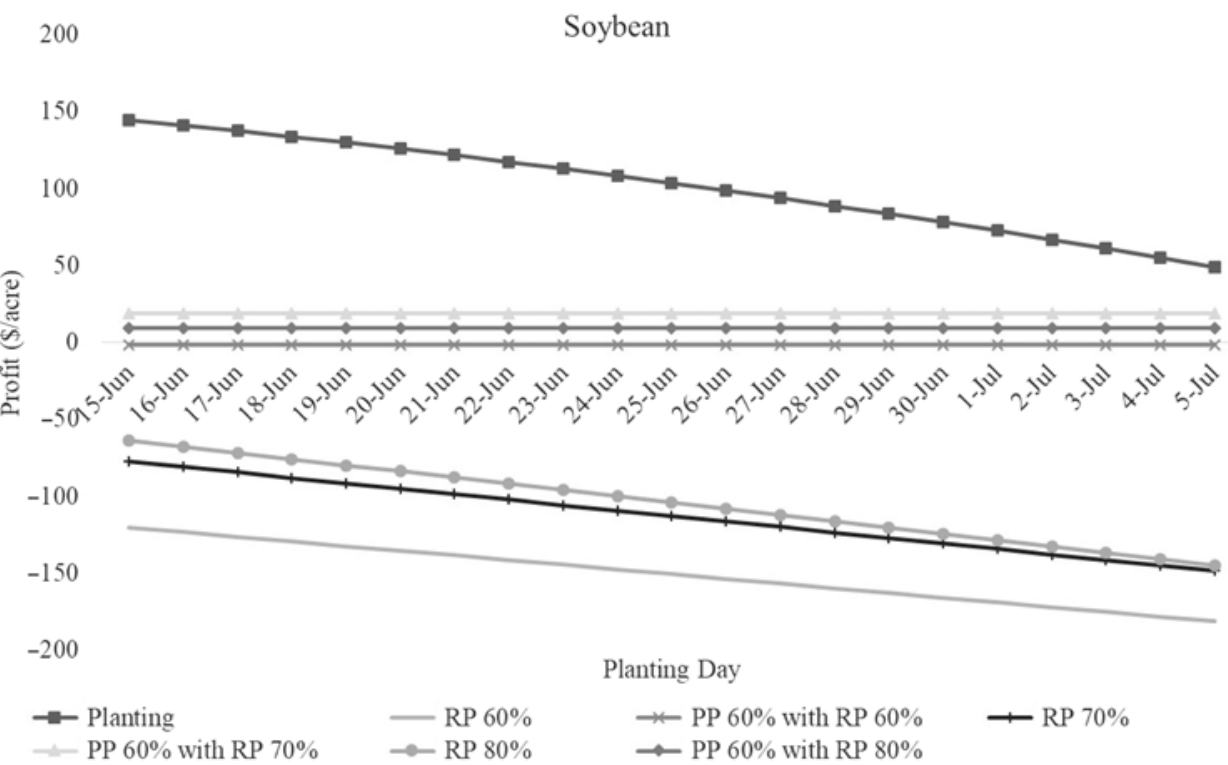

Figure 5. Estimated profits from planting, revenue protection (RP) with $60 \%, 70 \%$, and $80 \%$ coverage, and prevented planting indemnity payment (PP) with a prevented planting coverage factor of $60 \%$ for soybeans over the late planting period

factor or requiring producers to plant a cover crop on indemnified acres would not be necessary for soybean production.

Although the cost of production for corn is higher than for soybeans, approximately $60 \%$ of the soybean production cost occurs before planting, and $37 \%$ of the corn production cost occurs before planting (University of Tennessee, Department of Agricultural and Resource Economics, 
Table 4. Planting day in the late planting period when the profit from prevented planting payment becomes greater than profits from planting soybean

\begin{tabular}{|c|c|c|c|}
\hline Policy Scenario & $\begin{array}{l}\text { Revenue Protection with } \\
60 \% \text { Coverage Level }(\theta)\end{array}$ & $\begin{array}{l}\text { Revenue Protection with } \\
70 \% \text { Coverage Level }(\theta)\end{array}$ & $\begin{array}{l}\text { Revenue Protection with } \\
80 \% \text { Coverage Level }(\theta)\end{array}$ \\
\hline \multicolumn{4}{|c|}{ Prevented planting payment coverage factor $(\delta)$ of $60 \%$} \\
\hline $\begin{array}{l}\text { Without cover crop } \\
\text { restriction }\end{array}$ & After late planting period & After late planting period & After late planting period \\
\hline $\begin{array}{l}\text { With cover crop } \\
\text { restriction }\end{array}$ & After late planting period & After late planting period & After late planting period \\
\hline \multicolumn{4}{|c|}{ Prevented planting payment coverage factor $(\delta)$ of $55 \%$} \\
\hline $\begin{array}{l}\text { Without cover crop } \\
\text { restriction }\end{array}$ & After late planting period & After late planting period & After late planting period \\
\hline $\begin{array}{l}\text { With cover crop } \\
\text { restriction }\end{array}$ & After late planting period & After late planting period & After late planting period \\
\hline \multicolumn{4}{|c|}{ Prevented planting payment coverage factor $(\delta)$ of $50 \%$} \\
\hline $\begin{array}{l}\text { Without cover crop } \\
\text { restriction }\end{array}$ & After late planting period & After late planting period & After late planting period \\
\hline $\begin{array}{l}\text { With cover crop } \\
\text { restriction }\end{array}$ & After late planting period & After late planting period & After late planting period \\
\hline
\end{tabular}

Note: The late planting date for Tennessee soybeans is June 15 through July 5.

2017). This is because soybeans typically have a greater chemical cost prior to planting than corn because yield loss to weed pressure in soybeans is greater than for corn. This result demonstrates how accurately aligning prevented planting indemnity payments with the preplanting costs reduces moral hazard in prevented planting. This also shows that not all prevented planting coverage factors are equal across crops. These results provide USDA-RMA useful analysis and input into future adjustments to the prevented planting coverage factors.

\section{Conclusions}

Although there are concerns about moral hazard in the prevented planting provision of crop insurance, little research has explored the existence of the moral hazard in prevented planting. Therefore, we determined how changes to the prevented planting coverage factor affect corn and soybean producers' decision to plant their insured crop during the late planting period or abandon production and take the prevented planting indemnity payment. We also show how crop insurance coverage level affects this decision.

We build on a few previous studies by using agronomic data to estimate yield response to planting date during the late planting period. This allows us to determine the planting day in the late planting period when the producer would select the prevented planting payment over planting late. We also assess hypothetical policy changes to the prevented planting provision that could be considered by USDA-RMA when making future adjustments to the full prevented planting payment coverage factor.

Corn producers would be better off abandoning profitable corn production and taking their indemnity for the majority of the days in the late planting period. Moreover, higher crop insurance coverage levels provide producers with a greater incentive to abandon profitable corn production and accept the prevented planting payment. These finding suggests moral hazard exists in the prevented planting provision for producers. Reducing the prevented planting coverage factor for corn could likely reduce moral hazard in prevented planting, but the degree of the reduction 
will likely depend on the revenue protection coverage level. Conversely, we found moral hazard is not likely to occur for soybean production regardless of the revenue protection coverage level.

Although this work is unique and insightful, results are limited to a small region because of data exclusively coming from Tennessee. This article does, however, present an applied framework and model that could be extended to other regions of the United States. Also, these yield response experiments collected yield data from different planting dates that were not a function of delayed planting attributable to environmental factors such as excess or limited moisture. Actual producer yields would likely be lower than reported in this study because yield loss occurs because of delayed planting from some environmental factor that will further reduce yields. This means the net returns reported were likely higher than what a producer would actually receive. Although this does not affect the overall findings for corn, the results for soybean production could understate the moral hazard in prevented planting provision. Another interesting extension of this research and Kim and Kim's (2018) study would be to account for risk aversion in the producers' optimal decision.

Author ORCIDs. (D) Christopher N. Boyer 0000-0002-1393-8589

Acknowledgements. We thank the leadership and staff at the University of Tennessee Research and Education Centers for field research support. This research is also supported by U.S. Department of Agriculture, Cooperative State Research, Education, and Extension Service through Tennessee Hatch Project TEN00442.

\section{References}

Babcock, B.A., and D.A. Hennessy. "Input Demand under Yield and Revenue Insurance." American Journal of Agricultural Economics 78, 2(1996):416-27.

Boyer, C.N., M. Stefanini, J.A. Larson, S.A. Smith, A. Mengistu, and N. Bellaloui. "Profitability and Risk Analysis of Soybean Planting Date by Maturity Group.” Agronomy Journal 107, 6(2015):2253-62.

Coble, K.H., T.O. Knight, R.D. Pope, and J.R. Williams. “An Expected-Indemnity Approach to the Measurement of Moral Hazard in Crop Insurance." American Journal of Agricultural Economics 79, 1(1997):216-26.

Darby, H.M., and J.G. Lauer. "Planting Date and Hybrid Influence on Corn Forage Yield and Quality." Agronomy Journal 94, 2(2002):281-89.

Epplin, F.M., I. Hossain, and E.G. Krenzer, Jr. "Winter Wheat Fall-winter Forage Yield and Grain Yield Response to Planting Date in a Dual-Purpose System." Agricultural Systems 63, 3(2000):161-73.

Horowitz, J.K., and E. Lichtenberg. "Insurance, Moral Hazard, and Chemical Use in Agriculture." American Journal of Agricultural Economics 75, 4(1993):926-35.

Hossain, I., F.M. Epplin, and E.G. Krenzer, Jr. "Planting Date Influence on Dual-Purpose Winter Wheat Forage Yield, Grain Yield, and Test Weight." Agronomy Journal 95, 5(2003):1179-88.

Kim, T, and M.K. Kim. “Ex-post Moral Hazard in Prevented Planting.” Agricultural Economics 49, 6(2018):671-80.

Lauer, J.G., P.R. Carter, T.M. Wood, G. Diezel, D.W. Wiersma, R.E. Rand, and M.J. Mlynarek. "Corn Hybrid Response to Planting Date in the Northern Corn Belt.” Agronomy Journal 91, 5(1999):834-39.

Miranda, M.J., and J.W. Glauber. "Systemic Risk, Reinsurance, and the Failure of Crop Insurance Markets." American Journal of Agricultural Economics 79, 1(1997):206-15.

Rejesus, R.M., C.L. Escalante, and A.C. Lovell. "Share Tenancy, Ownership Structure, and Prevented Planting Claims in Crop Insurance." American Journal of Agricultural Economics 87, 1(2005):180-93.

Rejesus, R.M., A.C. Lovell, B.B. Little, and M.H. Cross. "Determinants of Anomalous Prevented Planting Claims: Theory and Evidence from Crop Insurance." Agricultural and Resource Economics Review 32, 2(2003):244-58.

Roberts, M.J., N. Key, and E. O’Donoghue. "Estimating the Extent of Moral Hazard in Crop Insurance Using Administrative Data." Review of Agricultural Economics 28, 3(2006):381-90.

SAS Institute Inc. SAS OnlineDoc ${ }^{\circledast}$ 9.4. Cary, NC: SAS Institute Inc., 2013.

Sherriff, G. 2005. "Efficient Waste? Why Farmers Over-Apply Nutrients and the Implications for Policy Design." Review of Agricultural Economics 27, 4(2005):542-57.

Smith, V.H., and B.K. Goodwin. "Crop Insurance, Moral Hazard, and Agricultural Chemical Use." American Journal of Agricultural Economics 78, 2(1996):428-38.

University of Tennessee, Department of Agricultural and Resource Economics. "Field Crop Budgets." Knoxville: University of Tennessee-Knoxville, 2017. Internet site: https://ag.tennessee.edu/arec/Pages/budgets.aspx (Accessed April 2018). 
University of Tennessee Extension. "Sorghum-Sudangrass Hybrids and Sudangrass." 2018. Internet site: http://utbfc.utk .edu/Content\%20Folders/Forages/Forage\%20Species/Forage\%20Species\%20Guide/SorghumandSudangrass.html (Accessed April 2018).

U.S. Congress. "H.R. $4217\left(103^{\text {rd }}\right)$ : Federal Crop Insurance Reform and Department of Agriculture Reauthorization Act of 1994." GovTrack, 1994. Internet site: https://www.govtrack.us/congress/bills/103/hr4217/text (Accessed April 2018).

U.S. Department of Agriculture, Federal Crop Insurance Corporation. Prevented Planting Standards Handbook 2016 and Succeeding Crop Years FCIC-25370-2. 2015. Internet site: https://www.rma.usda.gov/Topics/Prevented-Planting (Accessed April 2018).

U.S. Department of Agriculture, National Agricultural Statistics Service (USDA-NASS). 2018. “Quick Stats.” Internet site: http://quickstats.nass.usda.gov (Accessed April 2018).

U.S. Department of Agriculture, Natural Resource Conservation Service (USDA-NRCS). Cover Crops to Improve Soil Prevented Planting Fields. St. Paul, MN: USDA-NRCS, 2013. Internet site: http://www.nrcs.usda.gov/Internet/ FSE_DOCUMENTS/stelprdb1142714.pdf (Accessed April 2018).

U.S. Department of Agriculture, Office of Inspector General (USDA-OIG). RMA: Controls over Prevented Planting. Washington, DC: USDA-OIG, Audit Report 05601-0001-31, 2013. Internet site: https://www.usda.gov/oig/webdocs/ 05601-0001-31.pdf (Accessed April 2018).

U.S. Department of Agriculture, Risk Management Agency (USDA-RMA). “Prevented Planting Changes for $2017 . ” 2016$. Internet site: https://www.rma.usda.gov/News-Room/Frequently-Asked-Questions/Prevented-Planting-Coverage-FactorChanges-for-2019 (Accessed April 2018).

U.S. Department of Agriculture, Risk Management Agency (USDA-RMA). “Cost Estimator.” 2017a. Internet site: https://ewebapp.rma.usda.gov/apps/costestimator/Estimates/DetailedEstimate.aspx (Accessed April 2018).

U.S. Department of Agriculture, Risk Management Agency (USDA-RMA). "Price Discovery." 2017b. Internet site: https:// prodwebnlb.rma.usda.gov/apps/PriceDiscovery/GetPrices/YourPrice (Accessed April 2018).

Cite this article: Boyer CN and Aaron Smith S (2019). Evaluating Changes to Prevented Planting Provision on Moral Hazard. Journal of Agricultural and Applied Economics 51, 315-327. https://doi.org/10.1017/aae.2019.2 